MATEC Web of Conferences 46, 01005 (2016)

DOI: $10.1051 /$ matecconf/20164601005

(C) Owned by the authors, published by EDP Sciences, 2016

\title{
Development of full-scale façade tests in ISO TC92
}

\author{
Patrick van Hees \\ Department of Fire Safety Engineering, Lund University, Sweden
}

\begin{abstract}
During the 90ies, ISO TC92 SC1 started the development of full-scale tests for facades based upon an international review. The work resulted in two standards namely ISO 13785 part 1 and part 2. The work was performed in WG7 and a substantial input from international experts was given. The paper gives a short historical update on the development but also includes a short overview of the major type of hazards or risks, which can be identified with respect to façades and how they relate to the façade test standards developed. Finally the two methods are summarised and reference to recent work is given.
\end{abstract}

\section{BACKGROUND}

Within ISO TC92 SC1 fire development, WG7 deals mainly with full and intermediate reaction to fire tests. After completion of the ISO 9705 room corner test standard [1] in the early 90ies, ISO TC92 SC1 WG7 forwarded a questionnaire towards national member bodies in order to investigate what type of large-scale test needed to be developed after the room corner test. Two areas for further development were clearly indicated: sandwich panels and façades. The WG7 started up a task group to see the possibilities for development of standards in this area. For façades it was decided to develop both a screening method at small level and a large-scale test.

After a first screening of available large-scale tests, it was decided to look to three different national test methods being originally from Sweden, Germany and Canada [2-4]. The Swedish method SP 105 [4] was developed in the 80ies primarily by Lund University [5-7] and later incorporated and further developed in a SP method [8]. The German proposal was mainly based on the research conducted at Leipzig [9], which resulted in a draft German standard available during the 90ies [3]. Also other research was conducted in Germany [10] at that moment. This draft standard [3] has now been further developed in a newer version [11]. It is important to point out that the versions do have different thermal attacks, which is important when comparing the different test standards. The Canadian based on the UL method [2] was also available at that moment. Even that method has been further developed in more recent versions [12]. The major differences in the three methods were items such as fuel for the thermal attack (gas, wood or combustible liquid), level of thermal attack, dimensions and configurations (re-entrant corner or not), possibility for observations, etc. Although that intensive tests and documents were distributed in the WG7 only few information was published in peer review journals or at scientific conferences [13, 14]. Finally a more performance-based standard [15] was written having propane as the main ignition source but allowing other fuels such as wood and liquids as long as it could be shown

This is an Open Access article distributed under the terms of the Creative Commons Attribution License 2.0, which permits unrestricted use, distribution, and reproduction in any medium, provided the original work is properly cited. 


\section{MATEC Web of Conferences}

that the requirement of the total heat flux in the test standard could be fulfilled. The final level of total heat flux was established by international consensus. The standard set-up is explained more in detail in one of the next paragraphs.

Simultaneously a screening method was developed in the same WG7. This action was made as it was felt that large-scale tests are very expensive and there is need from industry to have cheaper product development tools. The standard was based on the results of a number of research project related to wooden façades [16, 17]. The work was also incorporated in a PhD dissertation [17] showing the link between the intermediate scale test and a large-scale test. The work resulted in an intermediate scale test [18]. However it was not checked if the test also correlated with the part 2.

During the development also European actions were undertaken. These actions resulted in a report dealing with the risk related to façades, an overview of a number of national standards and their link to the different risks [19]. The risk of façades will also be taken up in this paper in the next paragraph. After the publication of the ISO 13784 part 1 and 2 standards, a number of research publication were published showing comparison of different tests methods and different façade systems [20-23]. More recently work has been done in EOTA with respect to large-scale tests [24]. All these studies show the considerable risk associated to façades and the diversity of national and regional standards worldwide [25-33].

\section{HAZARD AND RISK DETERMINATIONS}

When considering façades and curtain walling systems, different types of hazards/risks can be considered. The risks and hazards considered in this paper are certainly not all types but they include the most important ones. Recent fires and research publications [20, 34] have shown that fires involving the exterior of a building should not be neglected. First there is the type of thermal attack or fire source. This thermal attack can be divided in to the following four main types

1. Fire inside the room

2. Fire in a room and outside the window

3. Fire at the exterior of the building close the façade e.g. container fire

4. Fire from another building.

Together with the type of fire source, different cases can be distinguished each addressing a specific hazard or risk. A schematic overview is given of four different hazards/risks below. Each of them has to be covered by a different type of testing set up or regulations and such attempts were made in earlier standardisation work [19]. Such work should always be done before introduction of new test methods in regulations. Regulations worldwide can namely address fire safety of façades in different ways. Examples are given in [35] for the Nordic regulation or in [28, 29] for insurance applications. Even routes of performance based design [36] and fire safety engineering [37] can be used. However this is considered outside the scope of this article.

\subsection{Case 1}

In this case the fire risk is penetration of the fire through the facade system from one level to another level trough e.g. the joint systems of the façade systems when a fire occurs inside a room. It can be considered that this type of hazard/risk is more linked to the evaluation of the fire resistance of a specific system. Specific attention should be given to the complexity of such system and the possible requirements the fire barrier border should or should not go throughout the façade system. This type of risk can also include spread of a fire from an attic down into the façade system [38]. 
$2^{\text {nd }}$ International Seminar for Fire Safety of Facades, Lund (Sweden), 2016

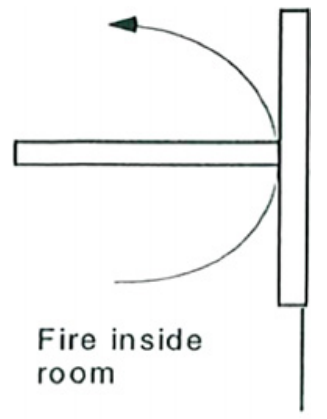

\section{Case 1}

Figure 1. Case 1 of typical hazard/risk involving a façade. (Reproduced from [19].)

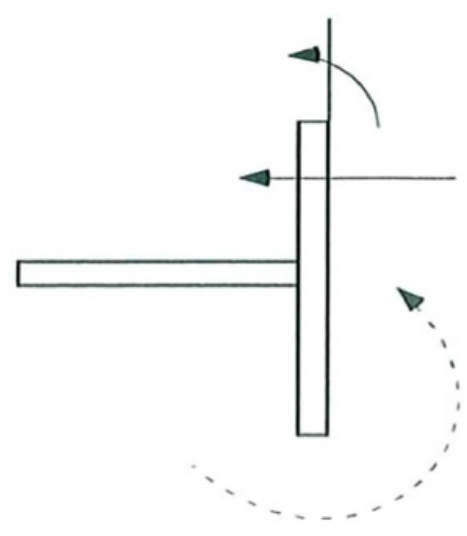

\section{Case 2}

Figure 2. Case 2 of typical hazard/risk involving a façade. (Reproduced from [19].)

\subsection{Case 2}

When a fire occurs outside a room through the window there is a risk of penetration of the fire through the façade system or through the glazing to the next floor. This can occur even when appropriate joints are covering the risk in case 1 . Also here most of the risk can be covered by a fire resistance test. Else regulation of safety distance can cover this risk (see case 2b, Fig. 3). An example is given in [39].

\subsection{Case 3}

When a fire occurs outside the window or at the exterior of the building (container fire) a considerable risk of fire spread on the façade surface or through the void between façade and building exists. Here the reaction to fire properties of the material used for the façade should be considered and is the main determining factor. However constructional details of windows and voids should not be neglected as well as means how to check fire stoppers inside the construction. 


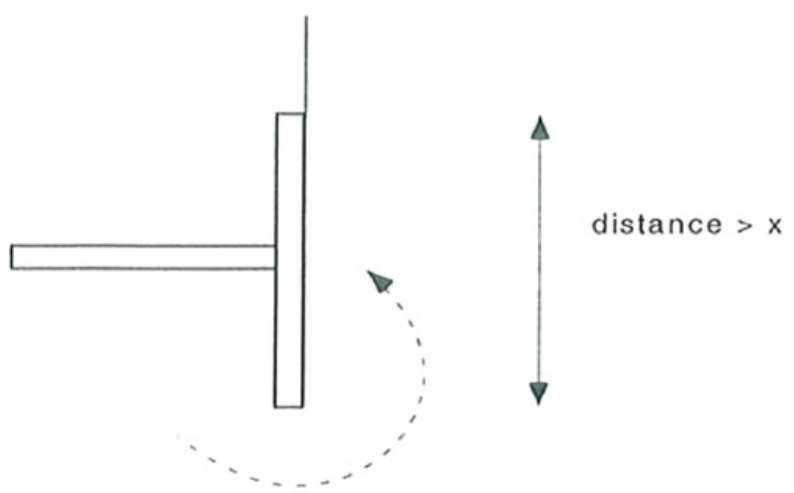

\section{Case $2 b$}

Figure 3. Case $2 b$ of typical hazard/risk involving a façade. (Reproduced from [19].)

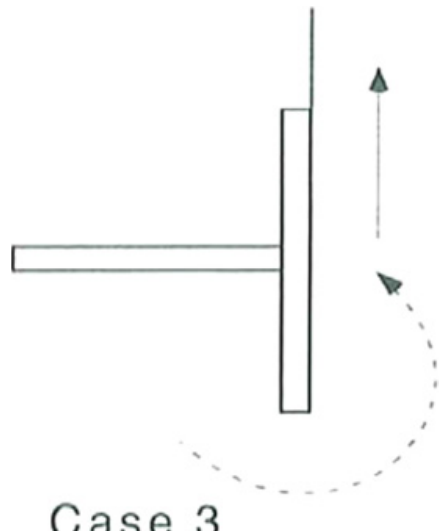

Figure 4. Case 3 of typical hazard/risk involving a façade. (Reproduced from [19].)

\subsection{Case 4 Falling parts or debris}

When a fire occurs through a window or al the exterior of the building nearby the façade it is important that no parts are falling clown from the façade. This would endanger the work of the rescue teams and also cause problems for evacuation of the building.

Constructional details from the façades are in this case extremely important. Glazing can be included if necessary but can be covered by other tests.

\section{INTERMEDIATE SCALE FAÇADES TEST ISO 13785 PART 1}

\subsection{Need of screening test}

Full-scale tests are expensive and there is need for the industry and for certification of products to reduce the scale of the tests. However it is necessary to explain the difficulties when scaling down the size of full-scale tests. Problems can occur if thermal exposure is not sufficient or not well scaled down. Another problem can be that the size of the specimens is too small so that mechanical behaviour of systems is 
$2^{\text {nd }}$ International Seminar for Fire Safety of Facades, Lund (Sweden), 2016

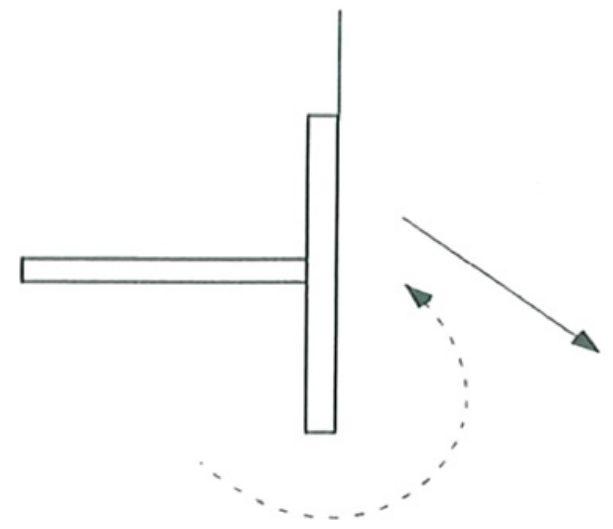

\section{Case 4}

Figure 5. Case 4 of typical hazard/risk involving a façade. (Reproduced from [19].)

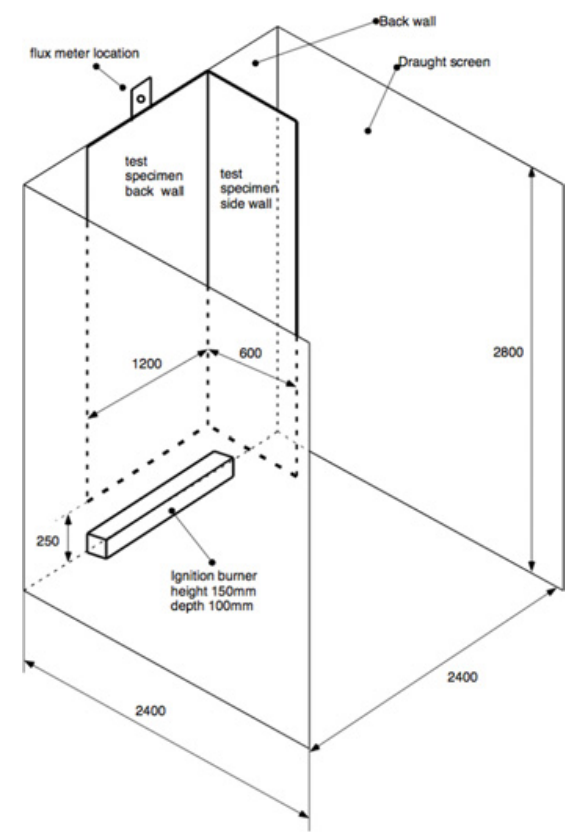

Figure 6. ISO 13785 part 1 - general view. (Reproduced from [18].)

not covered by the screening test. Screening tests can be used in combination with modelling but here it is important to investigate, verify and validate the models considerably [40].

\subsection{Description of test method}

Part 1 of the ISO standard consist of a test specimen of $1.2 \times 2.9 \mathrm{~m}$ which is exposed at the bottom by a line burner with a heat release rate of $100 \mathrm{~kW}$. Two draught screens are position perpendicularly to the 


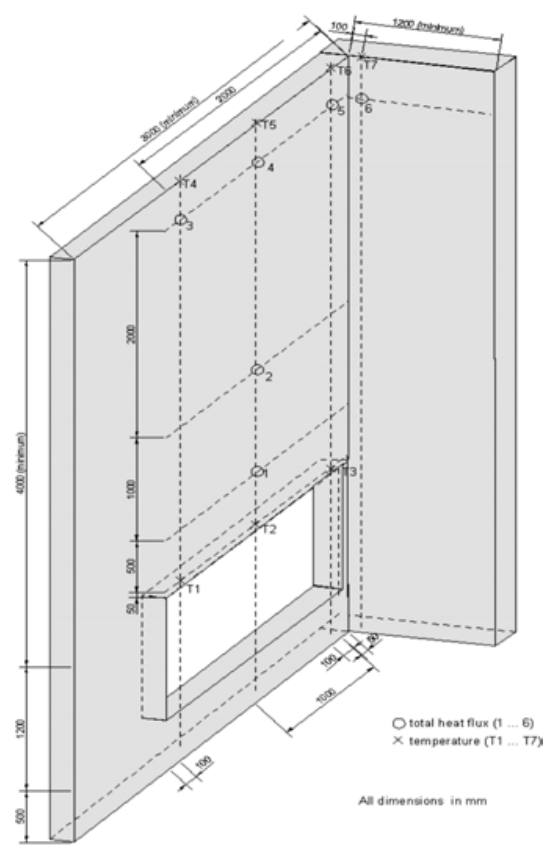

Figure 7. ISO 13785 part 2 - General view and measurement locations. (Reproduced from [15].)

wall to avoid unwanted draft and unstable flames. Measurement of temperature, total heat flux, flame spread and ignition are performed.

\subsection{Recent developments}

After the research performed with mainly wooden façades no real further investigations have been done on this method. Each systematic review of the standard in ISO resulted in confirmation of the standard.

\section{LARGE SCALE FAÇADES TEST ISO 13785 PART 2}

\subsection{Description of test method}

The method consists of a large-scale set-up built as an L-shaped configuration with two walls with dimensions of minimum $3 \times 4 \mathrm{~m}$ and $1.2 \times 4 \mathrm{~m}$ (width $\times$ height). The exposure to the façade construction is by flames emerging from a window with dimensions $2 \times 1.2 \mathrm{~m}$. The combustion chamber shall be of a regular shape with an internal volume not less than $20 \mathrm{~m}^{3}$ and not more than $100 \mathrm{~m}^{3}$. The recommended heat source is propane but other alternatives are given (wooden cribs and combustible liquids). Measurement of flame spread, temperature on surface and inside the construction as well as total heat fluxes at the surface are performed. An overview of the test set-up is given in Fig. 7 and different characteristics of the test method are listed in Table 1.

\subsection{Recent developments}

After development of the test standard there was little data available on the test method. However during the last 5 years a number national and regional projects were conducted which investigated the suitability of the method and compared it to other façade test standards [41-43]. During the latest systematic review 
$2^{\text {nd }}$ International Seminar for Fire Safety of Facades, Lund (Sweden), 2016

Table 1. Summary of the test method.

\begin{tabular}{|c|c|c|c|}
\hline $\begin{array}{l}\text { Characteristic of the } \\
\text { test method }\end{array}$ & Result & $\begin{array}{l}\text { Characteristic of the } \\
\text { test method }\end{array}$ & Result \\
\hline $\begin{array}{l}\text { Risks covered in the } \\
\text { actual test method }\end{array}$ & Case 3 & Height of rig $(\mathrm{m})$ & $\begin{array}{l}\text { Min. } 4 \mathrm{~m} \text { above } \\
\text { the opening }\end{array}$ \\
\hline Use in legislation & No & Width of rig (m) & Min. $3 \mathrm{~m}+\min 1.2 \mathrm{~m}$ \\
\hline Main set up & $\begin{array}{l}\text { Fire room with comer } \\
\text { shaped façade }\end{array}$ & $\begin{array}{l}\text { Opening front wall } \\
\text { (Width } \times \text { Height) }\end{array}$ & $2 \times 1 \mathrm{~m}$ \\
\hline Exposure levels & $\begin{array}{l}55 \pm 5 \mathrm{~kW} / \mathrm{m}^{2} \text { at } 0.5 \mathrm{~m} \\
35 \pm 5 \mathrm{~kW} / \mathrm{m}^{2} \text { at } 1.5 \mathrm{~m} \\
\text { Both values for at least } \\
15 \text { minutes }\end{array}$ & $\begin{array}{l}\text { Ventilation } \\
\text { opening back wall }\end{array}$ & $\begin{array}{l}\text { Dimensions subject } \\
\text { to calibrations }\end{array}$ \\
\hline Configuration & Corner & Ventilation & $\begin{array}{l}\text { Natural or forced through } \\
\text { ventilation opening }\end{array}$ \\
\hline $\begin{array}{l}\text { Windows and constructions } \\
\text { details included }\end{array}$ & No & Size of Fire room & Between 20 and $100 \mathrm{~m}^{3}$ \\
\hline Measurements & Temperature, Heat Flux & Heat source & $\begin{array}{l}\text { Propane as standard eat } \\
\text { source (wood, heptane } \\
\text { as alternatives) max. } 120 \mathrm{~g} / \mathrm{s} \\
\text { (approx. 5-6 MW) }\end{array}$ \\
\hline Mounted area & Both walls & & \\
\hline
\end{tabular}

in ISO a request was launched for revision of the standard. At this moment ISO TC 92 SC1 is waiting for a formal request to start revision of the method.

\section{CONCLUSIONS}

With the increase of high rise buildings and higher demands on thermal insulation, fire safety of external façades has become recently more important. Several hazards/risk can be identified with respect to façades and in order to tackle the flame spread risk on the surface, ISO TC92 SC 1 WG7 developed a large-scale test during the 90ies, which was published in 2001. As façades construction are very complex and are complete systems and not single materials or products, a full assessment by means of full-scale test is necessary. However there is a need for intermediate or screening to reduce testing and developing costs. Therefore an intermediate screening test was also developed by ISO and published in 2001. At the moment a myriad of national and regional test standards are available but the actual ISO test standard provides an internationally accepted alternative. Before introducing test standards into regulations, regulators should identify which risk they want to reduce and choose the appropriate performance criteria or safety levels. With this information, a suitable test method can be chosen or a suitable performance based solution based on fire engineering can be proposed.

\section{References}

[1] ISO 9705, "Fire Tests-Full-scale Room Test for Surface Products", ISO, 1993.

[2] DIN E 4102-20 (draft), "Brandverhalten von Baustoffen und Bauteilen, Teil 20: Besonderer Nachweis für das Brandverhalten von Außenwandbekleidungen”, DIN 2009.

[3] CAN/ULC-S134, "Standard Method of Fire Test of Exterior Wall Assemblies (CAN/ULC- S13492)", Underwriters Laboratories of Canada, Scarborough, Ontario, 1992.

[4] SP FIRE 105, Issue 5, "Large scale testing of facade systems", SP Boras Sweden, Dnr 171-79360, 1994.

[5] Ondrus, J., "Fire Hazards of Facades with Externally Applied Additional Thermal Insulation", Report LUTVDG/TVBB-3021 Lund Institute of Technology, Sweden. 1985. 
[6] Ondrus, J., and Pettersson, O., "Fire Hazards of Facades with Externally Applied Additional Thermal Insulation Full Scale Experiments", Report LUTVDG/TVBB-3025 Lund Institute of Technology, Sweden, 1986.

[7] Ondrus, J., and Pettersson, O., "Fire Hazards of Window-Frames of Plastics, Aluminium and Wood Full Scale Experiments - a comparison”, Report LUTVDG/TVBB-3037 Lund Institute of Technology, Sweden, 1987.

[8] Hermodsson, T. and Månsson, L., "Facades: Fire Testing of Materials and Constructions - A First Proposal for a Test Method (SP AR 1992:64)”, Swedish National Testing and Research Institute, 1992.

[9] Hildebrand, C., "Façade Fire Tests," Workshop report, Institut für Baustoffe, Leipzig, Germany, 1988.

[10] G. M. F. Jeffs, H. G. Klingelhöfer, F. H. Prager, and H. Rosteck, "Fire-performance of a Ventilated Facade Insulated with a B2-classified Rigid Polyurethane Foam", Fire and Materials, 10, Issue 2, 79-89, June 1986.

[11] DIN E 4102-20:2016-03 (draft): "Brandverhalten von Baustoffen und Bauteilen - Teil 20: Besonderer Nachweis für das Brandverhalten von Außenwandbekleidungen”, DIN 2016.

[12] CAN/ULC-S134, "Standard Method of Fire Test of Exterior Wall Assemblies", Underwriters Laboratories of Canada, 2013.

[13] Sumathipala, K. and Kotthoff, I., "The Development of an International Fire Test Standard for Facades", Poster, Proceedings of the Fifth International Symposium Fire Safety Science. Melbourne, 1997.

[14] Babrauskas, V., "Façade Fire Tests: Towards an International Test Standard", Fire Technology, Third Quarter, pp. 219-230, 1996.

[15] ISO 13785 part 2, "Reaction to fire tests for façades — Part 2: Large scale test", ISO, 2001.

[16] Hakkarainen, T. and Oksanen, T., "Fire safety assessment of wooden facades", Fire and Materials, 26: pp. 7-27. doi: 10.1002/fam.780, 2002.

[17] Hakkarainen, T., "Studies on fire safety assessment of construction products", Doctoral thesis, VTT publication nr. 459, Espoo 2002.

[18] ISO 13785 part 1, "Reaction to fire tests for façades — Part 1: Intermediate-scale test", ISO, 2001.

[19] Van Hees P., "Semi Natural Fire test for façades and curtain wall systems", Nordtest report 143399, SP AR 2000:39, Borås 2000.

[20] White N., Delichatsios, M., "Fire Hazards of Exterior Wall Assemblies Containing Combustible Components", CSIRO report EP142293, CSIRO, June 2014.

[21] Wade, C.A. and Clampett, J.C., "Fire Performance of Exterior Claddings", BRANZ Report FCR 1. Building Research Association of New Zealand. Judgeford, New Zealand, 2000.

[22] Wade, C.A., "Fire Performance of External Wall Claddings Under a Performance-based Building Code", Fire and Materials, 19, pp 127-132, 1995.

[23] Smolkaa, M., Messerschmidt, B., Scott, J., le Madec, B., "Semi-natural test methods to evaluate fire safety of wall claddings", $1^{\text {st }}$ International Seminar for Fire Safety of Facades, Paris, MATEC Web of Conferences Volume 9, MATEC Web of Conference, DOI: 10.1051/matecconf/20130902012, 2013.

[24] Kotthoff, I., Riemsch-Speer, I., "Mechanism of fire spread on facades and the new Technical Report of EOTA Large-scale fire performance testing of external wall cladding systems", 1st International Seminar for Fire Safety of Facades, Paris, MATEC Web of Conferences 9, DOI: 10.1051/matecconf/20130902010, 2013.

[25] Önorm B 3800-5 (draft), "Fire behaviour of building materials and components - Part 5: Fire behaviour of facades - Requirements, tests and evaluations", Austrian Standards Institute, 2003.

[26] BS 8414-1, "Fire performance of external cladding systems. Part 1: Test method for nonloadbearing external cladding systems applied to the masonry face of a building", BSI, 2015. 
[27] BS 8414-2, "Fire performance of external cladding systems, Part 2: Test method for nonloadbearing external cladding systems fixed to and supported by a structural steel frame", BSI, 2015.

[28] LPS 158: Issue 2.0:2010, "Requirements and tests for LPCB approval of non-loadbearing external cladding systems applied to the masonry face of a building, 2010.

[29] LPS 158: Issue 1.0:2010, Requirements and tests for LPCB approval of non-loadbearing external cladding systems fixed to and supported by a structural steel frame, 2010.

[30] L.E.P.I.R. 2 (Local expérimental pour incendie réel à deux niveaux), Arrêté du 10 septembre 1970 relatif à la classification des façades vitrées par rapport au danger d'incendie, Version consolidée au 16 février 2016, French test method for fire spread, downloaded from www.legifrance. gouv. fr on 20151220, 1970.

[31] NFPA 285, "Standard Fire Test Method for Evaluation of Fire Propagation Characteristics of Exterior Non-Load-Bearing Wall Assemblies Containing Combustible Components", NFPA, 2012.

[32] NFPA 268, "Standard Test Method for Determining Ignitibility of Exterior Wall Assemblies Using a Radiant Heat Energy Source", NFPA, 2012.

[33] BR 135, "Fire performance of external thermal insulation for walls of multi-storey buildings, second edition", BRE report, 2003.

[34] Peng, L., Ni, Z., Huang, X., "Review on the fire safety of exterior wall claddings in high-rise buildings in China", 9th Asia-Oceania Symposium on Fire Science and Technology, Procedia Engineering 62 (2013) pp. 663-670, Tokyo, 2015.

[35] Strömgren, M., Albrektsson, J., Johansson, A., Almgren, E., "Comparative analysis of façade regulations in the Nordic countries, $1^{\text {st }}$ International Seminar for Fire Safety of Facades, MATEC Web of Conferences 9, DOI: 10.1051/matecconf/20130901003, 2013.

[36] Mikkola, E., Hakkarainen, T., and Matala, A., "Fire safety of EPS ETICS in residential multistorey buildings", VTT report VTT-R-04632-13, Espoo, 2013.

[37] Didieux, F., "Facade fire - fire safety engineering methodology", 1st International Seminar for Fire Safety of Facades, Paris, MATEC Web of Conferences 9, MATEC Web of Conference, DOI: 10.1051/matecconf/20130903010, 2013.

[38] Johansson, N., "Fallstudie av konstruktionsbränder (in Swedish)", LTH report 3191, ISSN: 14023504 ISRN: LUTVDG/TVBB-3191—SE, Lund, 2015.

[39] Règlement de sécurité contre l'incendie relatif aux établissements recevant du public Livre II: Dispositions applicables aux établissements des quatre premières catégories Titre premier: Dispositions generals, Chapitre II: Construction Instruction technique $n>249$ Relative aux façades, http://www.sitesecurite.com/ERPIT/IT24900.htm\#0, Downloaded 20151220, 2015.

[40] Van Hees, P., "Validation and Verification of Fire Models for Fire Safety Engineering", Procedia Engineering, 62, 2013, Pages 154-168, 9th Asia-Oceania Symposium on Fire Science and Technology, DOI:10.1016/j.proeng.2013.08.052, 2013.

[41] Yoshioka, H., Ohmiya, Y., Masaki Noaki; M. And Yoshida, M., "Large-scale Facade Fire Tests Conducted Based on ISO 13785-2 with Noncombustible Facade Specimens", Fire Science and Technology 31, No. 1, 1-22, 2012.

[42] Macdonald, M., "A comparison of BS 8414-1 \& -2, draft DIN 4102-20, ISO 13785-1 \& -2”, EN 13823 and EN ISO 11925-2”, Report number CC275194 issue 2. BRE Global Ltd. 2012.

[43] Messerschmidt, B., Fellman, J., "Fire Testing of ETICS a comparative study". Proceedings of International Conference Interflam 2013, Windsor, UK. Interscience Communications, 2013. 